\title{
'HE IS THE IMAGE AND GLORY OF GOD, BUT WOMAN ...' (1 COR 11:7): 'UNVEILING' THE UNDERSTANDING OF THE IMAGO DEI
}

\author{
David T Williams \\ Department of Historical and Contextual Theology \\ University of Fort Hare
}

\begin{abstract}
The reference to the imago Dei in 1 Corinthians 11:7 has been largely ignored, probably because what it seems to say is hardly popular. Can it be that women are not in the image of God? Nevertheless, if the passage is taken seriously, it provides a fresh understanding of the meaning of the image, complementing the preferred interpretations of the meaning of the image in the ideas of dominion and interpersonal relations. It may be suggested that its focus must fall on the difference in creation of men and women in Genesis. The image of God resides in the direct bestowal of life from God. Notably, the New Testament locates the image only in Christ, which is consistent with this view. Emphatically, if a person, man or woman, accepts the offer of new life, he or she then becomes in the image. In this case, there is total sexual equality.
\end{abstract}

Key Words: Image of God, Trinity, Sexual Equality, Regeneration

\section{The image and glory of God}

In the modern world, Paul's remark in 1 Corinthians 11:7 is particularly striking,

a man ... is the image and glory of God, but woman is the glory of man.

Hardly an acceptable thing to say these days! But Paul did say it! Does this mean that woman is not in the image of God but the man is? Is it the case that "Paul gets himself into a theological quagmire" (Hays 1997:186)? Or is the lack of reference to the woman being in God's image only an example of something that is the case but just not actually said? Almost unanimously in the early Church and Middle Ages, the view was that only the male is in the image of God (Van Huyssteen 2006:132); the first to query this being Augustine (Børresen 1995:199), but surely this obvious deduction cannot be the case? Or is it an example of Paul's oft-claimed misogyny? Paul does seem to be quite definite; in this case is there a clue here to a fuller understanding of the meaning of the image?

\section{Imago Dei}

Considering how rare actual reference to the idea of the image is in the Bible, it does receive much scholarly attention. However, the paucity of references is made up for by the fact that the context of each is very significant; and this would be true for the Corinthians passage. Although there are few direct references, the image is implied in the whole of Old Testament thought and occurs in some of the greatest passages in the New Testament (Cairns 1973:26, 40). 
Interpretations of the meaning of the image are indeed legion. The most obvious inference is that God resembles people physically. 'Image', selem, usually has to do with physical similarity (Miller 1972:291, Clines 1968:73). This was indeed made by the Old Testament scholar Gunkel; Köhler even feeling that the image related to the upright posture of people (Westermann 1974:57), an idea also held by the Mormons (Sherlock 1996:74). Ecclesiastes 7:29 does refer to people being made upright, but this would appear to bear the sense of moral goodness. Any anthropomorphism must surely be excluded.

For Barth, there is even a danger of idolatry in seeking to identify the image (Sherlock 1996:89). Significantly, Hill (1984:197) points out a parallel to Genesis 1:27 in Exodus 20:4, where the two key words 'image' and 'likeness' occur. Other images are forbidden because they must be false, and in any case are unnecessary as humanity is there. Even if the Bible does speak of God's hands and face, these are generally understood as figurative expressions (but cf Clines 1968:70). However, Hill (1984:198) does point out that the Bible is full of images; he concludes that people may think but not make them. Von Rad (1963:56) emphasises that it is the whole person who is in the image of God, so that the image does include bodily form. He refers to Ezekiel's vision of God (Ez 1:26), where there was an appearance of human form.

In all writers up to Aquinas, the image is rationality (Cairns 1973:116); this was particularly so for Augustine, who took half his de Trinitate seeking to discover the image (Cairns 1973:99), so sought it in the human mind (Sherlock 1996:79). This is an idea supported by the fact that Jesus is the logos. Rationality is perhaps the most noticeable feature of humanity (Hill 1984:204). For Philo, there could be no relation to bodily features (Van Huyssteen 2006:127). An Enlightenment worldview finds this attractive, as it does a suggestion that the image lies in human autonomy. However, as people are created, they are not independent (Erickson 1998:510). Brunner does highlight the point that freedom means that people can relate to God in a full way; only a free person can really love (Hoekema 1986:53). Erickson (1998:531) also queries a reference to reason, as it would imply that the intelligent are more in God's image. Van Huyssteen (2006:127) then notes that 'unfortunately' this was often linked to misogyny.

Closely related to this, in view of the prevalence of the Greek dualist worldview, is that the image refers to the spiritual aspect of humanity. People are spiritual, in the image of God who is spirit (Jn 4:24). Less common, but understandable, is to see the image in creativity, especially as the first occurrence is in the creation narrative. Creativity is also an attribute which does seem unique to humanity. Likewise the suggestion of morality, a link made rather ironically by James (3:9); people are still expected to be moral after the fall, yet they curse God's image.

Such a substantive interpretation of the image is less adhered to today. There is no idea of the former in the Bible (Thielicke 1979:157). Luther notes the fact that God is essentially active, but also that most of the suggested qualities could be seen as more fully manifested in the devil than in people (Thielicke 1979:157, 161). The modern tendency is to see the essence of human nature in its relations (e.g. Hall 1986:113). Being is rather 'being-with' (German mitsein) (1986:117). A person is personal just by the relationships that he or she is in. A person cannot really be human without relating to others, and to God (Brunner 1939:140); a third essential relationship, to the world, should be added. Likewise Pannenberg (1970:2) sees the uniqueness of people in their participation and openness to every stratum of being (also Medley 2002:176). Most recent opinion is then that the image pertains to the function of humanity, and specifically in its relationships (Hoekema 1986:69). Hoekema (1986:65) refers with approval to the view of Bavinck, that people are 
the image, not have the image. Barth, in agreement with Brunner, thus saw the image not as a quality possessed by people but in relationship; it is dynamic not static (Erickson 1998:526). Thus, between God and people there is not an analogy of being (analogia entis), but of relation (analogia relationis) (Hoekema 1986:50).

In the modern world, the vastly preferred understanding is that the image refers to human dominion over the creation. This dominion is imaging the Lordship of God (Erickson 1998:528), so is functional, and in particular, relational. God created 'as', not 'in', his image (Clines 1968:80). God is to humanity as humanity to the rest of creation (Hill 1984:199). Unlike the substantialist suggestions which are basically speculative, the rationale for this lies in the Biblical text, for the connection is clearly made in Genesis 1:27. In the ancient world, the image of the king, as in a statue, showed his authority (Hoekema 1986:67); an example of this is Nebuchadnezzar (Dan 3:1f). A later example is when Jesus referred to the image of Caesar on a coin ( $\mathrm{Lk}$ 20:24). This even pertains in the modern world, where government offices often contain a picture of the head of state. Strikingly, for the ancient near East tended to say that only the king was in the image of the gods (Sherlock 1996:37), the Bible identifies humanity. In the image, people then not only mirror, but also represent God (Hoekema 1986:67).

A second suggestion is also based on the original text. Barth (1958:197f) is credited with the suggestion that it refers to human plurality. The creation text does strikingly say, 'let us make ...', and immediately refers to humanity being in male and female. What would then be reasonable is that it is in their plurality that people are in the image of God. Clines (1968:62-9) concludes, in comparison with other suggestions, that the plural does reflect at least duality in God. It must also be noted here that Barth does not just wish to see the image as referring to human plurality, even if it is only this that is actually demanded by the Genesis passage, but believed that this plurality must be relational. Justifiably, the fact of male and female does immediately include the idea of the relationship between them. Barth (1958:195) sees the image in "confrontation, in the juxtaposition and conjunction of man and woman".

Significantly, in this single case, God, elohim, actually governs a plural (Sherlock 1996:34), thereby stressing it. Although grammatically a plural, this generally takes a singular verb; this means that the obvious implication of the plurality of elohim is of the Trinity, as most of the early Fathers believed (Hill 1984:200). Barth did not want to be so categorical, but he does indicate that the confrontation in the image is more fully described in the doctrine of the Trinity (1958:192f, cf Cairns 1973:32). Hill (1984:200) suggests that Genesis proves a 'hunch' of this in its portrayal of plurality, which is vindicated by the New Testament development. This indicates that people are in imago Trinitatis. Augustine also saw people in the image of the Trinity, but located this in the make-up of the mind, not in their plurality.

In a strong critique of Barth's view, Bird (1974:150) believes that the second statement of Genesis 1:27 "adds to the first; it does not explicate it"; it speaks of human fertility, not the image. She actually sees the text as distinguishing people from deity as God is sexless, and relating them rather to the animals (1974:149). The blessing for both (Gen 1:22, 28) relates to fertility. Against Barth, she therefore denies that the image resides in sexual difference. The text may be taken as a fuller description of the nature of the plurality of people as God created. However, while the text cannot mean that God is male and female, sexuality is more than just for reproduction (Grenz 2001:272, 7). Deuteronomy 32:18 uses male and female imagery in respect of God. Especially if the image does reflect some idea of form, people do image God in sexual identity, as well as in other characteristics. Sands 
(2010:35-6) also provides a good critique of the relational view; he argues that the vocational, so dominion, view subsumes the legitimate insights of the other views into a 'more biblically faithful perspective' (2010:28). However, most rather follow Barth here and so see the image referred to in this plurality. In any case, human plurality in cooperation is essential for dominion.

What must then be affirmed is that a relational understanding in no way negates the previous suggestions, which are usually made in a substantialist framework. Nevertheless, it may be suggested that in fact each more traditional suggestion is subsumed in the more comprehensive trinitarian image. Dominion requires rationality (Hill 1984:203); it requires reason (Pannenberg 1970:27).

Probably it is better to see the image in both substantialist and relational terms, as Luther, distinguishing a 'private' and a 'public' likeness (Thielicke 1979:156). While Medley (2002:42) observes that personhood has often been reduced to individual selfconsciousness, the opposite is to see it as just relational. Rather they complement; the substantial qualities are the means for relating (1986:116). While the former results in autonomy, the latter gives heteronomy; LaCugna (1993:290, also Medley 2002:42) rather advocates theonomy.

\section{Corinthians 11:7}

The Corinthians passage has been largely ignored in the discussion. It is generally assumed that the text cannot mean what it actually says, but that the image is present in all men and women (e.g. Grudem 1994:457). Cairns $(1973: 28,36)$ says that this is indicated in both Genesis 5 and 9:6. Genesis 1:27 and 5:2 are often taken as stating that the original creation of the image was of the man and woman and so demand that both men and women are equally in the image of God (e.g. Hill 1984:199, Bird 1974:159). Fatum (1995:52), however, feels that the fact of equality of the sexes (Gal 3:28) has tended to distort the approach to 1 Corinthians 11; what is needed is to understand how both texts can be seen to be true, not just skating over the latter as due to culture or prejudice.

Of course contributing to the neglect of the passage is the obvious fact that it depends on the specific figures of Adam and Eve; modern thought, whether scientific or theological, has largely rejected any hint of historicity. It might, however, just be observed that the fundamental text dealing with the image is also in a 'questionable' passage, in Genesis 1. However, Paul would almost certainly have accepted the story as historical, and indeed bases a significant aspect of his understanding of the means of salvation squarely on the shoulders of Adam in Romans 5. (And not, significantly, on Eve! Is that because she was not in the image of God? And is that why she was tempted?) More than this, recent discussion on origins has tended to accept the basic idea of evolution, while noting that the scientific facts do suggest that in the course of evolution God did intervene at specific points (Williams 2010:392). In this case, the creation of the primal couple was probably one of those specific direct creations. Auld (2005:262) says that both Genesis 1 and 2 conclude with a deliberate divine intervention which enables relationship, the human with the divine, and woman with man.

But if Paul means exactly what he says in the passage, what does this say about the meaning of the image? In 1 Corinthians 11:7, it is the male who is in the image of God. Bird (1974:159) believes that this is what the author of Genesis 1 intended to say; in this case there is no necessary equality of the sexes in that verse. For Beckwith, the image of God is in man directly, but in woman indirectly (Grenz 2001:290), the view of Calvin (van 
Huyssteen 2006:131). Even Augustine said that as made from man, the woman could not be in the image (de Trinitate, cited by Van Huyssteen 2006:128); however, as for him the image lay in the mind, it resides in both sexes (Børresen:1995:204). Not surprisingly Luther then saw no real distinction as regards the image, despite a measure of perhaps inevitable chauvinism (Van Huyssteen 2006:130); 'still she was a woman' (Luther, in Douglass 1995:242). Roberts (2006:14) says that the man reflects God in his lordship in a way that the woman does not; he says that both are equally in the image but the man then reflects God's glory in a way that the woman does not. Clines (1968:72) asks "is it not significant that when God appears in a theophany, it is always a male form that is seen?"

But unless God is indeed male, which must be problematic, even when it is appreciated that in the Hebrew view of anthropology, the bodily and spiritual should not be separated unduly (cf Clines 1968:59), and in the light of Genesis 1:27 (1968:72), what does this say about the meaning of the image? This distinction between the sexes must then surely relate back to Genesis 2, where the man is described as being formed from the dust, and given life from the breath of God, while the woman is formed from the rib of the man, so shares his life. In this case, the image resides in the direct gift of life from God.

The real distinction from animals is not in qualities such as reason (Cairns 1973:118), but human distinctiveness is by participation in the life of God (Brunner 1939:110). Jenson sees the image in relation to God; people are unique not in what God says about them, but to them (Van Huyssteen 2006:147). Relationship in itself does not constitute humanity, as it occurs between animals, including people of course; it is not something that people do as they are in the image. Even though it is the relationships that primarily make a person human, it is in relating to God that full humanity comes. A human is only really personal by participating in God (Medley 2002:43). Calvin said that the image is present when a person truly loves God (Cairns 1973:136). Humanity is unique as standing before God (Cairns 1973:181). It is insofar as people are in relation to God, that they are the image. Clines (1968:81) points out that in the Ancient Near East, an image was the dwelling place of the spirit of the being whose image it was, and that idols were derided (e.g. Jer 10:14) as having no breath (ruach). So it is as the man had the breath of God, his 'vitality' (1968:89), that he was in the image. The relationship between people is secondary to the fundamental relationship, which is with God. There is no record, as with the first man, of animals being given life as a distinct act; in particular, it is the breath of God which Genesis 2 understands as characteristic of humanity (Blocher 1984:80, 7). Psalm 39:7 puts selem and hebel (breath) in parallelism (Clines 1968:75). Westermann (1974:47) also notes that the creation of people is not simply by the word; however, of course, the material from which they were made, the dust, was.

Lenski (1963:441) points out that the image always bears the connotation of derivation, unlike likeness. Likewise in the New Testament; Grenz (2001:209) says that unlike homoioma, where resemblance may be accidental, eikon indicates derivation. Fee (1987:515) indeed says that it is because he was created directly that the man is in God's image. Similarly, Grosheide (1979:255) writes that "the apostle implies that a man, by virtue of the manner of his creation can be called the image of God." Robertson \& Plummer (1911:231) explain that there is a contrast in the verbs used in 1 Corinthians 11:7; whereas the man is (huparchōn) in the image of God, the woman is (estin) the glory of the man; the first means the original constitution. Likewise, the other key term, 'glory', also implies direct derivation, so that the man is the glory of God, the woman of the man (1 Cor 11:7).

This understanding is confirmed by the fact that the New Testament sees only Christ as the image of God in a full sense, for he is begotten by the Father (Jn 1:14). Christ is the 
image in the New Testament as Christ is in a full relation to God. It is through his resurrection that Jesus is in the image of God, and through this enables others to be also (Van Huyssteen 2006:124). Jesus could then say that "he who has seen me has seen the Father" (Jn 14:11); the uniqueness of Adam is then reflected in that of Christ in Romans 5. Romans 1:4 notes the designation of Christ as Son, so imaging God, in the giving of resurrection life. Christians are then the image derivatively while Christ is inherently (Roberts 2006:15). In salvation, there is a direct relation to God so people are in the image, and become conformed to Christ in the development of that relationship.

While it is often suggested that the image is a reflection of dominion in that kings commonly set up statues as a symbol of their authority over an area, an example being that of Nebuchadnezzar (Dan 3:1), Miller (1972:296) believes that the purpose of the statues was rather as memorials to the kings and their mighty deeds. This is particularly appropriate where Christ is seen as the image, reflecting the acts of creation and salvation, and even for redeemed people, who rejoice in their own salvation. Christians are, after all, witnesses for God!

It would then follow that people are not naturally in the image of God; certainly the New Testament would not see humanity as being in the image, but rather identifies it with Christ. Although Genesis 9:6, after the flood, and particularly James 3:9, are often cited as indicating that people are still in the image, these do not demand that people are still fully in the image, but that humanity was created in the image (as Berkouwer, in Hoekema 1986:61). Hoekema (1986:15) also sees this meaning in Genesis 5:1, although it uses the word 'likeness'; he does not see this as significant, but perhaps it emphasizes that the fullness of the image had gone. James 3:9 can rather refer to the original creation; it also uses the word gegonotas, where the perfect tense indicates a present state affected by a past action. If people were fully in the image, the present tense would be used. People no longer properly bear the image (Hoekema 1986:31). In this regard, Hill (1984:201) speaks of a 'mythic' idea held by some Rabbis, that Adam's descendents were not in the image of God. Perhaps significantly, Genesis 5:3 refers to Seth being in the image and likeness of Adam, through whom he received life; he is not referred to as in the image of God in that verse, but as the likeness. So while Sands (2010:30) says that Genesis 5:3 parallels Genesis 1:2628, and appears to mean that Adam passed the image to his offspring, he points out that on this point there is some debate. Thus although it is often believed that Seth is then in the image of God, Roberts (2006:10) is quite right to use the word 'presumably'. Genesis 5 does not deal with the transmission of the divine image (Clines 1968:100). Indeed, Genesis rather describes the creation of humanity not as, but according to the image, who is Christ (Hill 1984:207).

The idea of the image then highlights not the nature reflecting the prototype, but the act of the making, or in this case the impartation of life. Here Westermann (1974:59) explains the fewness of references to the image as in the context of creation, and so suggests that it is only relevant to the creative act (or the act of re-creation in the last case, Genesis 9:6). Support for this may be found in that where Christ is referred to as the image of God, this is often in the context of creation (Col 1:15, Heb 1:3). Hoekema (1986:21) notes that Hebrews 1:3 describes Christ as the 'exact representation' of God's being. The word is charakterr, sometimes translated 'very stamp'. A seal or stamp shows all the features of what produced it (Hoekema 1986:21), but must draw attention to the action that gave the impression. Hebrews 1:3 relates the act of incarnation. Indeed the Hebrew selem, 'image', which means something cut or carved (Hoekema 1986:13), draws attention to the action; the other word, demut, means 'resemblance', so does not bear that nuance. This might well explain the 
reference to the image in Genesis 9; murder is then doing violence to God as the original source of life (Hoekema 1986:16). The connection between the image and shedding of blood is then clear (cf Miller 1972:300) in the light of the location of life in the blood (Lev 17:11). Miller (1972:301) in fact draws attention to the similarity between the Hebrew for 'likeness', demut, and 'blood', dam, and that in Mesopotamian tradition, people were created from divine blood, mixed with clay.

A further observation is that it is the man who is the source of the gender of the embryo, and not the woman. It is the man, and not the woman, who images the fact that God created the sexual differentiation in people. Then relating to the other relational interpretation, Hodge (1964:210) believes that dominion was vested in the male (would that be why sin was ascribed to Adam?).

This means that it is only in the presence of new life that the growth of a person into the full expression of the image is possible. Salvation, so new life, is through faith; faith gives the renewal of the image (Brunner, in Cairns 1973:167). The substantialist qualities all depend on the relationship between people and God (Hall 1986:132). Likewise the idea of fatherhood must link strongly to giving of the image to children; God is only Father to those who believe (Cairns 1973:279). As Grenz (2001:250) says, "Christ is God's image because he is God's Son"; the same holds for people. Whereas the image of God was lost, or at least marred by sin, originally at the fall, the giving of new life to a person in salvation effectively restores the image, at least potentially; only then is he or she enabled to start conforming to that image. The Orthodox emphasis on salvation by theosis (cf 1 Pet 1:4) reflects this as life is given by being 'in Christ' (Grenz 2001:324); the Spirit 'divinises human persons' (Medley 2002:46). When a person receives new life from God that he or she then becomes the image of God, restoring what was damaged in the fall. Grenz (2001:224) notes that the New Testament references to the image always have an eschatological nuance, and Thielicke (1979:152), that they provide a task, an imperative. Both sexes are then equally in the image, as long as both have new life, which is what Paul also affirms in Galatians 3:28, as long as both the sexes are regenerate; indeed, for the Galatians, a return to law and circumcision would then also be a return to bondage to gender discrimination (Fatum1995:64). Børresen (1995:187) affirms that traditional Christian anthropology understands women's parity with men in redemption. Fatum (1995:62) comments that in Christ, people revert to the original status described in Genesis $1: 27$. If they are not in Christ, then the woman is indeed subordinate, as evidenced in many religions. Incidentally, Grenz (2001:270) comments that the account of the creation of women is uniquely Biblical. Fatum (1995:68) then adds that 1 Corinthians 11 must be seen in the context of the three following chapters, so respecting difference but complementary (12), love (13) and empowering (14).

This means that there is then no difference, as regards the image, between male and female after their re-creation. 1 Corinthians 11:7 can hardly be a justification for any inherent subordination of women. In any case, even if the writer of Genesis 2 probably accepted the subordination of women, he explains it not as due to creation, but sin (Hill 1984:144, 169). Incidentally, Erickson (1998:564) believes that neged (helpmeet, Gen 2:18) implies equality, although Grudem (1994:461) says that 'helper' does mean inferiority. Brunner (1939:359) then suggests that in a fallen world, 'helping' means inferiority, but that this was not the intention. So while Wolff (1974:166) points out that in the Old Testament a man owned his wife, "Paul lifts the whole male-female relationship onto a breath-taking plane" (Milne 1982:100). It must also be observed that it was only in Christ that Jew and Gentile were able to relate properly, and be equal (Gal 3:28). Medley (2002:78) critiques 
the anthropocentrism that sees a woman only imaging God by relating to a man; rather a woman becomes the image only by relating to God. Incidentally, there must also be a critique of the common medieval notion that a woman had to 'become' a male, from a misinterpretation of Ephesians 4:13 (Børresen 1995:183); a view doubtless exacerbated by Aristotle's influential idea that a woman is a misbegotten man (Douglass 1995:236). Calvin rather interprets this as the fullness of life in Christ (Douglass 1995:256). Although it was a common medieval view that a woman was only for propagation, the companionship of marriage was also re-affirmed with Calvin (Douglass 1995:259). Interestingly, the Rabbis said that the woman was not taken from the head of the man to dominate, or from the feet to serve, but from the side to be a companion (Sherlock 1996:40).

Calvin also debunks a common view that the temporal priority of Adam gave superiority, citing the case of John the Baptist preceding Christ (Douglass 1995:257, also noting a view that Eve was an improvement!). Indeed, origin does not give superiority; very significantly for the understanding of 1 Corinthians 11:7, the eastern tradition sees the Father as the source of divinity of the other Persons, yet in perichōressis the three are equal; there is a parallel here to the relation of man and woman.

\section{Other New Testament References}

Although still few, there are more references to the idea of the image in the New Testament than in the Old. The main word is eikon, which is the Septuagint rendering of selem, but there are other words which bear the same sense, especially character (Heb 1:3) and morphe (Phil 2:6) (Hall 1986:79). What is significant is that while most of these would seem to have little connection with the two relational understandings, they generally do relate to the idea of the impartation of new life. Indeed the only real exception to this is James 3:9, which significantly, does not use 'image', but 'likeness' (homoiōsis). This verse does, however, link to Genesis 9:6 and of course brings to mind Jesus' warning on the sinfulness of harsh words.

2 Corinthians 3:18 and 1 Corinthians 15:49 make a particularly vivid contrast between the old and new lives. Grenz (2001:211) makes a connection from the context of 2 Corinthians 3:18 to wisdom, which in Jewish tradition was both the agent of creation and of conversion. For Philo, wisdom was the eikōn theou (also Wisd 7:26). Significantly, 1 Corinthians 15:27 quotes Psalm 8, and immediately after glorying in the defeat of the last enemy, death. There is a contrast between the first and second Adam, death and life; Christ, as image, has dominion, here over death (Grenz 2001:235); he became 'life-giving' through his resurrection. "We shall also bear the image of the man of heaven" (1 Cor 15:49), where the verb has the sense of 'putting on', often used of clothing (Grenz 2001:238); people put on Christ and bear his image. Christians image Christ by participating in the life of the Spirit (Medley 2002:147).

In both 2 Corinthians 3 and 1 Corinthians 15 there are explicit links to the Spirit, and so probably to Genesis 2:7. It is of course the Spirit who is the agent of the development of new life in sanctification. Although not explicit, the idea of the image is implied in Ephesians 4:24, where the new nature of righteousness and holiness is described as in creation kata Theon. Likewise Colossians 3:10 speaks of being renewed in knowledge after the image, where knowledge implies relationship. In Romans 8:29, there is a conformity (summorphous) to the image; this is from the foreknowledge of God, where the idea of knowing is again more than the intellectual (Grenz 2001:226), and often carries the nuance of relationship; Bruce (1963:177) speaks of 'electing grace'. Here this would be particularly 
implied by the prefix sum-, which will remind of the Pauline 'in Christ' (Grenz 2001:229). Romans 8:29 then sees Christ as the first-born among many; he enabled their new life. Grenz (2001:231) indeed sees Romans 8:29 as expressing the goal of Genesis 1:27, a humanity conformed to Christ. The link between image and life-giving also appears in Colossians 1:15 with the description of Christ, the image, as 'firstborn', a title crucial to the passage (Grenz 2001:215), and with salvation in 2 Corinthians 4:4. The passage brings together creation and resurrection. Finally, Hebrews 1:3 relates the image to physical creation (cf Gen 1:27, 1 Cor 8:6), but places its focus on forgiveness (Grenz 2001:222); the link to purification from sins brings in the requirement for the impartation of new life. Here the word charakterr has the idea of the production of an image, as on a coin; Christ is the agent for imprinting the divine image (Grenz 2001:222).

\section{A Threefold Understanding of the Image}

Many, such as Medley (2002:2), Hoekema (1986:75f), and Hall (1986:124f) then suggest that Genesis 1 incorporates the relationships to God, to other people, and to nature, all of which are exemplified in Christ. There is a slight difference in respect of the relationship of humanity to the inanimate and animate creation, the former being described as subduing, the latter as dominion (Gen 1:28); Wolff (1974:94) speaks of four relations, but the essence of rule is the same. "Man is thus not simply master of the animals, but king of the earth" (Clines 1968:99). Westermann (1974:49) feels that the reference to human sex in Genesis 1:27 links people to the animals (also Bird 1974:149, cf Grenz 2001:272); in contrast, dominion distinguishes from them. At the same time, the possession of life contrasts with the inanimate creation, but of course people link to it by being material; however, the last relationship does not image God as spiritual.

It is then significant that the suggested understanding serves to supply what is essentially the missing relationship. The dominion interpretation is in the context of the environment, and the plurality view in the context of other people, but there has not really been an understanding that is located in the context of the relationship to God. The Corinthian one satisfyingly fills the gap. It is interesting that in reaction to the anthropocentrism that is often seen in Genesis 1, the modern emphasis is often presented as biocentrism. Gnanaken (2006:118) comments that while this provides the needed alternative to anthropocentrism, it conflicts with the biblically justifiable solution for the Christian; pure biocentrism tends to deify nature, while pure anthropocentrism will divinize humans; he advocates theocentrism.

Christ is then the exemplar for the correct manifestation of each of the relationships. Hall (1986:185) particularly refers to that over the environment, but the same is true of the others (Eph 5:23, Jn 14:11). The goals for humanity comprise the fulfilment of the three relationships, human flourishing (so life), welfare of the planet and communion (Medley 2002:1). Here Hall (1986:133) emphasises that the three relationships are all processes in development, moreover, that all are gifts.

\section{Renewing the Image}

It then follows that the entry of sin not only damages each aspect of the image, but also the inter-relating of them. The term 'fragmented' (Thielicke 1979:151) is very apt.

It is obviously the possession of life that was affected by the entry of sin. The Genesis account speaks of the entry of death, so appropriate in the light of the temptation of the serpent. Irenaeus (Adv Haer 5.6.1) even suggested that in a state of sin, people are only 
body and soul (cf. Hoekema 1986:34). He felt that the image is retained but the likeness is lost; Cairns (1973:28), however, believes that there is parallelism in Genesis 1:27, so Irenaeus' distinction between image and likeness is wrong. In this case, other aspects of the image are naturally affected.

In the perversion of the image, dominion was then damaged (Hoekema 1986:85). Indeed, one immediate result of the fall was God's pronouncement that the earth would no longer be so fruitful (Gen 3:17f). Incidentally this indicates that the original granting of dominion did include authority over the inanimate creation - in contradiction to the suggestion that it was only over the animals. At the same time, there was a loss of a relationship of trust with the animals, which then feared people (Gen 9:2). This would seem not to have been the case immediately after the fall, and enabled the salvation of animals by Noah. It does, however, then indicate the cumulative effect of sin.

The reflection of the image in plurality was also affected. The harmony that should pertain in marriage was marred. Relationships not only lost depth but were corrupted in other ways. Temporary liaisons in fornication and adultery became common; perversity in sexual relationships, such as in homosexuality resulted. Significantly, good relationships in marriage are a result of a committed desire and will, which themselves were affected by sin; the various aspects of the image interrelate.

In this case, it is the establishment of the key relationship with God that is critical. It not only means that both men and women are in the image of God, enabled to develop all that this means, but that the other relationships are healed. It is in their manifestation of new life that a correct relationship to the earth is possible, and that interpersonal relationships are correct. Not only are men and women equal in the sight of God (Gal 3:28), but they can relate to each other without the perversion produced by $\sin$.

There is a second reference to a veil in the Corinthian correspondence.

And we all, with unveiled face, beholding the glory of the Lord, are being changed into his likeness (eikōn) from one degree of glory to another (2 Cor 3:18).

What is significant is that it is when a person turns to the Lord that the veil is removed (3:16), and perhaps even more exciting, is that this pertains to 'all' and that it is in this there is freedom. Again significantly, this is through the Spirit, who gave that direct relationship to God to the man, and now gives the relationships of the image to both men and women. The transformation of 2 Corinthians 3:18 affects all relationships (Grenz 2001:249). There is the reversal of the falling short of the glory of God due to sin (Rom 3:23) (Cairns 1973:46). By their relation to Christ, people share his glory, sharing in his image which 'is pictured as glory' in that Christ is the perfect reflection of the glory of God (cf Jn 1:14, Cairns 1973:45). It is in him that both men and women can fulfil their destiny; humanity was created for God's glory (Is 43:7 cf Eph 1:11-2). It is in him that there is the shining forth of attributes, which is what 'glory' means (Lenski 1963:442).

The woman is the glory of the man (1 Cor 11:7). But through the gift of new life she is no longer the glory of Adam, but of the new Adam, Christ, and in this way is in the image of God. 


\section{BIBLIOGRAPHY}

Auld, G 2005. imago dei in Genesis: speaking in the image of God. Expository Times 116(8):259-62.

Barth, K 1958. Church dogmatics. Vol 3(1): the doctrine of creation. Edinburgh: T \& T Clark.

Bird, PA 1981. "Male and female he created them": Gen 1:27b in the context of the priestly account of creation. Harvard theological review 74(2):129-59.

Blocher, H 1984. In the beginning: the opening chapters of Genesis. Downers Grove, Ill. Leicester: IVP.

Børresen, KE (ed.) 1995. The image of God: gender models in Judaeo-Christian tradition. Minneapolis: Fortress.

Børresen, KE 1995. God's image, man's image? Patristic interpretation of Gen. 1,27 and 1 Cor. 11,7. Børresen 1995:187-209.

Bruce, FF 1963. The epistle of Paul to the Romans: an introduction and commentary. London: Tyndale.

Brunner, E 1939. Man in revolt: a Christian anthropology. London: Lutterworth.

Cairns, D 1973. The image of God in man (rev ed.). London: Collins (Fontana).

Clines, DJA 1968. The image of God in man. Tyndale Bulletin 19:53-103.

Douglass, JD 1995. The image of God in women as seen in Luther and Calvin. Børresen 1995:236-66.

Erickson, MJ 1998. Christian theology (2nd ed.). Grand Rapids: Baker Academic.

Fatum, L 1995. Image of God and glory of man: women in the Pauline congregations. Børresen 1995:50-133.

Fee, GD 1987. The first epistle to the Corinthians. Grand Rapids: Eerdmans.

Gnanaken, K 2006. Creation, Christians and environmental stewardship. Evangelical Review of Theology 30(2):110-20.

Grenz, SJ 2001. The social God and the relational self: a Trinitarian theology of the Imago Dei. Louisville: Westminster John Knox.

Grosheide, FW 1979. Commentary on the first epistle to the Corinthians: the English text with introduction, exposition and notes. Grand Rapids: Eerdmans.

Grudem, W 1994. Systematic theology: an introduction to Biblical doctrine. Grand Rapids: Zondervan.

Hall, DJ 1986. Imaging God: dominion as stewardship. Grand Rapids: Eerdmans/New York: Friendship press, for Commission on Stewardship, National Council of the Churches of Christ in the U.S.A.

Hays, RB 1997. First Corinthians. Louisville: John Knox (Interpretation: a Bible commentary for teaching and preaching).

Hill, E 1984. Being human: a Biblical perspective. London: Geoffrey Chapman.

Hodge, C 1964. A commentary on the first epistle to the Corinthians. London: Banner of Truth.

Hoekema, AA 1986. Created in God's image. Grand Rapids: Eerdmans/Exeter: Paternoster. LaCugna, C M 1993. God for us: the Trinity and Christian life. San Francisco: Harper Collins. 
Lenski, RCH 1963. The interpretation of St Paul's first and second epistles to the Corinthians. Minneapolis, Minn: Augsburg.

Medley, MS 2002. Imago Trinitatis: toward a relational understanding of becoming human. Lanham, MD: University press of America.

Miller, JM 1972. In the 'image' and 'likeness' of God. Journal of Biblical Literature 91:289-304.

Milne, B 1982. Know the truth: a handbook of Christian belief. Leicester: Inter-Varsity. Pannenberg, W 1970. What is man? Philadelphia: Fortress.

Roberts, M 2006. The image of God and holiness. Foundations 55:10-6.

Robertson, AC \& Plummer, A 1911. A critical and exegetical commentary on the first epistle of St. Paul to the Corinthians. Edinburgh: T \& T Clark.

Sands, P 2010. The Imago Dei as Vocation. Evangelical Quarterly 82(1):28-41.

Sherlock, C 1996. The doctrine of humanity. Leicester: Inter-Varsity.

Thielicke, H 1979. Theological ethics. Vol 1: Foundations. Grand Rapids: Eerdmans.

Van Huyssteen, JW 2006. Alone in the world? Human uniqueness in science and theology. Grand Rapids: Eerdmans.

Von Rad, G 1963. Genesis: a commentary (2nd. ed.). London:SCM.

Westermann, C 1974. Creation. Philadelphia: Fortress.

Williams, DT 2010. Evolution through kenōsis. Expository Times 121(8):390-4.

Wolff, HW 1974. Anthropology of the Old Testament. Philadelphia: Fortress. 